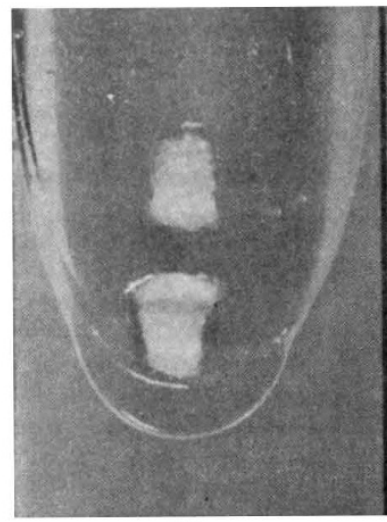

(a)

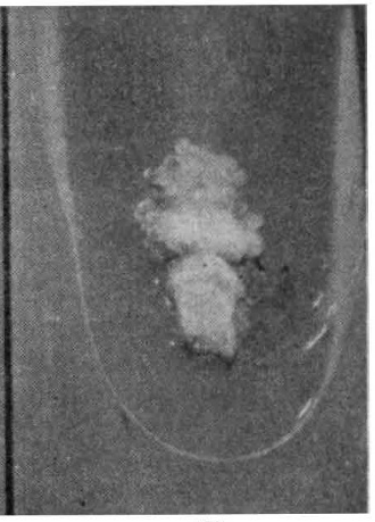

(b)

Fig. 1. CULTURES OF CAMBIUM FROM Vinca rosea: (a) BEFORE, AND (b) AFTER THEIR UNION in vitro. (PHOTOGRAPH BY J. A. CARLILE.

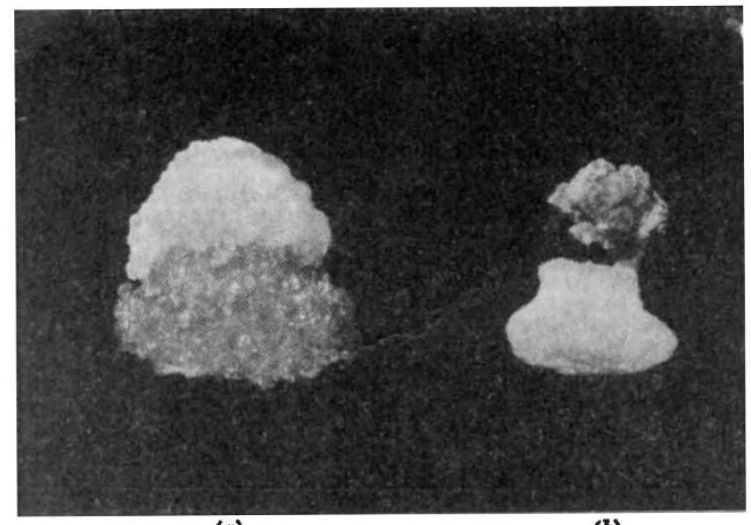

(a)

(b)

Fig. 2. (a) CROWN GALI TUMOUR TISSUE GRAFTED ON TO NORMAI Helianthus TISSUE, SHOWING DISORGANISED TROIIFERATICN INDUCED IN 'STOCK' BY GROWTH-FACTORS PRODCCED BY TUMOUR TISSUE (b) UNSUCCESSFUL GRAFT SHOWING DFAD ILNCCR TISSUE AND NORMAL APPEARANCE OF THE 'STOCR'. (FHOTCGRAIH BY J. A. CARLILE.)

Fig. 2 shows the result of grafting bacteria-free crown gall sunflower tissue, kindly provided by Dr. P. R. White ${ }^{2}$, on to a stem culture of normal sunflower tissue. The general appearance of such grafts after four weeks growth is shown in Fig. $2 a$. The tumour tissue developed as a white, structureless mass, initiating, as it grew, a rapid but disorganised type of growth in the normal stock. The brown discoloration of the cortical cells in this tissue and their swollen hyperhydric appearance resembled the effect produced on normal Helianthus tissue by concentrations of indole acetic acid higher than $10^{-6}$, suggesting that this substance or one similar in physiological effect is produced and in which union did not take place is shown in Fig. $2 \mathrm{~b}$. Here the normal stock is flrm, white and retains its original organisation; the The distock'. These experiments suggest that the technique of in vitro grafting may be of special value as a means of demonstrating growth hormones produced by various types of living tissue, in addition to throwing new light on the actual mechanism of graft un

R. S. DE ROPP.

Agricultural Research Council,

Department of Animal and Plant Pathology,

Rockefeller Institute for Medical Research, Princeton, New Jersey.

Gautheret, R. J., Thesis, p. 249 (Paris, 1935).

White, P. R., and Braun, A. C., Cancer Res., 2, 597 (1942).

\section{Fractionation of Human Plasma with Ether}

IN treating plasma from time-expired blood according to the method described by McFarlane ${ }^{2}$ for the removal of lipoid from human serum, it was found that in addition to extracting lipoid from combination with plasma protein, the flbrinogen was also removed. The quantitative removal of fibrinogen was effected by adjusting the plasma with citric removal of flbrinogen was effected by adjusting the plasma with citric tions of extracted plasma protein obtained in this manner, after the removal of the dissolved ether and readjustment to $p \mathrm{H} 7 \cdot 0$, have provided a satisfactory transfusion fluid, remaining crystal clear for more than two years

The flbrinogen obtained by this treatment was in an intractable form, which precluded its recovery for such clinical uses as have been developed by $\mathbf{E}$. J. Cohn and his colleagues ${ }^{3}$. The ether method has therefore been reinvestigated

Blood taken into a trisodium citrate anticoagulant is cooled to $1^{\circ} \mathrm{C}$. and centrifuged within 24 hours. The anated plas cooled to through paper pulp at $1^{\circ} \mathrm{C}$ to remove all cellular material Tibrinogen is precipitated by the addition of 11 vol per temperature is emerature is maintained at ofi so ofr, so far as possible, and the sedimented material removed by plasma flbrinogen, and electrophoresis of a solution indicates that flasma ibrinogen accounts for 40 per cent of the total protein.

The greater proportion of the plasma protein occluded in the initial flbrinogen precipitate can be removed by suspending the precipitate fibrinogen precipitate can be removed by suspending the precipitate in citrate-saline containing $10 \mathrm{vol}$, per cent ether at $1^{\circ} \mathrm{C}$. and recentri-
fuging. Further puriflcation can be effected by dissolving the washed fuging. Further puriflcation can be effected by dissolving the washed precipitate in citrate-saline and reprecipitating with ether. Electroand globulins have been removed, but on prolonged electrophoresis and globulins have been removed, but on prolonged electrophoresis the flbrinogen curve becomes asymmetrical owing to the separation a material of slightly higher mobility than the main component.

The supernatant from the original flbrinogen precipitation is adjusted at $1^{\circ}$ C. to $p$ H $5 \cdot 3-5 \cdot 4$ with $0.2 M$ citric acid, and allowed to stand overnight at this temperature. A yellow precipitate containing prothrombin equivalent to a yield of 40,000 units/litre plasma settles out, and is separated in a manner similar to that described for the flbrinogen. It is washed twice by suspending in distilled water at $1^{\circ} \mathrm{C}$. and recentrifuging, to remove substances present in plasma which tend to cause a considerable reduction in the yield of thrombin during the subsequent conversion of the prothrombin. The washed precipitate is suspended in citrate saline and dissolves completely when adjusted with $0 \cdot 2 M$ sodium hydroxide to $p \vec{H} 7 \cdot 0$. On conversion to thrombin with placental thromboplastin at optimal calcium ion concentration a small amount of flbrin separates, and after removing this a product is obtained with an activity of about $20 \mathrm{units} / \mathrm{mgm}$. protein. The final yield of thrombin is about $25,000 \mathrm{units} / \mathrm{litre}$ of plasma. While this thrombin is not of a high degree of purity, it is a satisfactory material for clinical purposes and the solutions obtained contain 150-200 units/ml.

One unit of thrombin is defined as the quantity which in $1 \mathrm{ml}$. of a flbrinogen solution containing $0 \cdot 1-0 \cdot 2 \mathrm{gm} . / 100 \mathrm{ml}$. will produce clotting in 15 sec. at $37^{\circ} \mathrm{C}$.

Following the removal of the prothrombin, the remainder of the plasma is frozen to $-30^{\circ} \mathrm{C}$. with excess ether, and during the thawing out the protein is concentrated. The aqueous layer is syphoned off and the dissolved ether removed by allowing jets of air to impinge on the surface of the fluid. The extracted protein solution is adjusted to $p \mathbf{H} 7 \cdot 0$ and diluted to a standard protein content. Traces of flbrinogen which remain in this material are removed by the addition of $0.5 \mathrm{unit}$ of thrombin $/ \mathrm{ml}$., followed by cooling to $1^{\circ} \mathrm{C}$., when a fllmy clot separof thrombin/ml., followed by cooling to $1^{\circ} \mathrm{C}$., when a filmy clot separates. This maw mado insoluble by freezing to $-30^{\circ} \mathrm{C}$. and allowing to thaw slowly. The resulting fluid is clarifled and passed through a sterilizing fllter. The product is crystal clear, has a pale green tinge, periods.

The fibrinogen and thrombin preserved by freeze-drying have been used successfully in skin grafting and nerve-suturing operations and in the production of flbrin foam for hæmostasis. The extracted plasma protein residue is a satisfactory transfusion fluid.

The whole of this processing is carried out aseptically and no bacterial contamination has been detected at any stage.

\section{The Lister Institute,}

R. A. KEKWICK.

London, S.W.1.

Feb. 21.

MARGARET E. MACKAY. B. R. RECORD. (Medical Research Council.)

McFarlane, A. S., Nature, 140, 139 (1942).

Kekwick, R. A., McFarlane, A.'S., and Mackay, M. E., unpublished. sohn, E. J., et al., J. Clin. Invest., 23, No. 4 (1944).

- Brit. Patent Application 31199/45.

\section{Parthenocarpy and Accompanying Hormonal Syndromes Induced by Unrelated Chemicals}

SEEDLESS fruits have been obtained by Gustafson ${ }^{1}$ using $œ$ strin and by Wong ${ }^{2}$ who used colchicine. Having confirmed ${ }^{3}$ the finding of Sass that ethyl mercury phosphate has hormonal and other effects similar to those of colchicine, I compared the effects of colchicine, acenaphthene and ethyl mercury phosphate in the form of 'Ceresan'. Seeds of cucumber (var. Danish Mustard) were germinated on filte paper moistened initially with a 1 in 1,000 suspension of 'Ceresan' which was reduced tenfold by successive waterings. After about five days the seedlings were potted. When flowering began, the flowers were sprayed with a 1 in 2,000 suspension of 'Ceresan'. Acenaphthene was supplied as a sprinkling of crystals under the moist flter-paper. and just before flowering the flower-buds were enclosed in glass tubes carrying acenaphthene crystals on their walls.

Both acenaphthene and the mercury compound exerted toxic effects under the conditions stated; growth was reduced and roots were thickened. Treated plants flowered later than the controls. Table 1 gives the average numbers of fruit set per plant on a total of 264 plants. 